\title{
CSR Activities and Responsibilities by FMCG Companies of India: A Customer Perspective
}

Effulgence

Vol. 15 No. 2

July-December, 2017

Rukmini Devi Institute of Advanced Studies

E-mail : effulgence@rdias.ac.in, Website : www.rdias.ac.in http:/ / effulgence.rdias.ac.in/user/default.aspx https:/ /dx.doi.org/10.33601/effulgence.rdias/v15/i2/2017/52-63

\section{Shivani Raheja}

\begin{abstract}
Corporate Social Responsibility is a strategic weapon that is often used by the corporates as per the whims and fantasies of board and managers to project the image of being a 'Good Corporate citizen'. It can be used as a marketing tool, wherein the Corporates use CSR as the basis of Segmenting, Targeting and Positioning (STP) in order to decide their social initiatives. They Segment the CSR domain broadly in three Segments Planet, People, Profit and specifically in ten areas as per the basis of various areas/ themes listed in schedule VII of the Company's Act 2013. Managers then carefully identify and target the areas, to show the concern towards Planet, People and Profit by way of meeting Triple Bottom Line (TBL). But, are the customers supportive of these CSR initiatives taken up the Corporates, while making purchases? Numerous researches have proved that focussed CSR initiatives improve the financial health of the companies but a very less number of significant studies have been done in Indian Context to check the end consumers' understanding and perception about CSR. The biggest challenge for the managers lies in the core of identifying a mechanism to explain "where to spend" and "how to communicate"?

This paper is a partial submission of the research work done under Ph.D. requirement in the specified topic. This research paper is a contributory part of the major study done under the Ph. D submission requirements of the author. In this paper, the author has tried to explain the CSR from the consumer's perception, what FMCG companies in India do in the name of such CSR practises, an attempt has been made to check whether the consumers are supportive of such CSR practises and finally to identify the gaps between what companies does and what the consumers expect.

Keywords: Corporate Social Responsibility, Strategic Weapon, Corporate Citizen, Corporate Conscience, Social Performance, Sustainability Strategy, CSR Practices, Segmenting, Targeting and Positioning, Company's Act 2013, Triple Bottom Line, Profitability, Consumer's Perception, FMCG, India.
\end{abstract}




\section{INTRODUCTION}

$\mathrm{C}$ SR in India is a relatively new term as compared with rest of the world. Globally, different authors have defined it in different ways. On the basis of the works done by different authors, CSR is effectively known as one of the following by the stakeholders of the business: corporate citizenship, corporate conscience, social performance, or sustainable responsible business, but what it actually means is a practice of corporate self-regulation integrated into its business model.

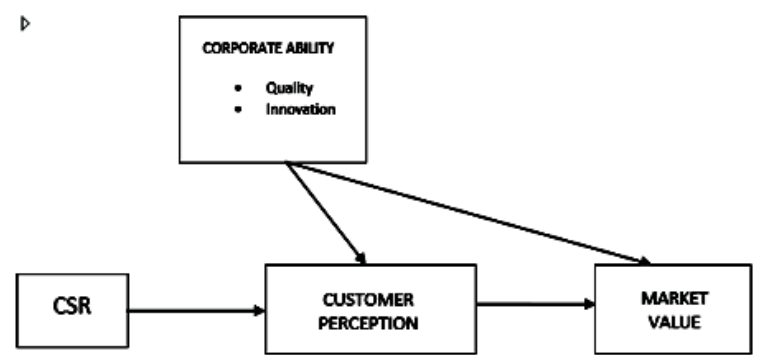

Fig 1 : Customer Perception and CSR

\section{Source: Adapted from Luo \& Bhattacharya, 2006}

Looking at a larger picture of this, Corporate Social Responsibility is concerned with treating the stakeholders of a company or institution ethically or in a responsible manner (acceptable according to international norms) and the Stakeholders exist both within a firm or institution and outside. Corporate citizenship is all about the extent to which the businesses meet legal, ethical and economic responsibilities ranging from Elementary initiatives to Innovative Techniques and finally to Transforming strategies. Corporate Conscience simply states that the corporates though are artificial entities but should be morally responsible persons. The term Social performance is all inclusive of the firm's economic, financial and environmental responsibility. CSR is a process to achieve sustainable development in societies and thus the notion of Sustainable responsible business directs the firms to go green and meet the. triple bottom line
(People, Planet, Profit).

"The social responsibility of business encompasses the economic, legal, ethical and discretionary expectations that a society has of organizations at a given point in time." -Caroll

\section{The Pyramid of Social Responsibility}

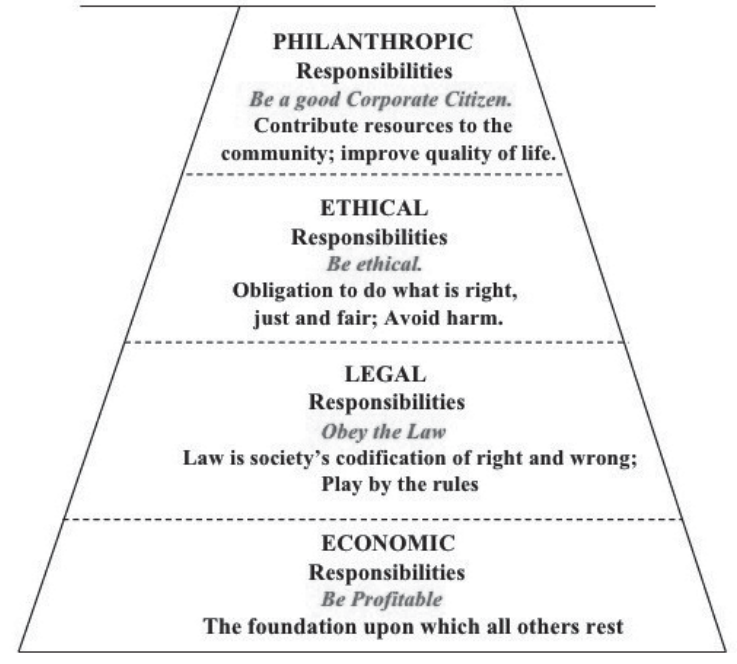

Source: Carroll (1991)

Fig: 2 Carroll's Pyramid

The literature has identified five major dimensions of CSR: the consumers, the employees, the shareholders, the society and the environment, among others. However, promoting creativity, green production, optimum utilization of resources, finding value generating solution for the environmental and other societal problems is yet another way of contributing towards society, and has emerged as the contemporary CSR dimensions. The CSR initiatives taken up by firms are generally similar types of projects often regarded as the pet projects. The flaunted CSR initiatives by firms are generally short lived \& ornamental as they usually offer minimal benefits to the business, society or nation at large. Hence, the biggest challenge for the corporates lies in identifying the areas of "where to spend" and methods for "how to communicate"?

Many FMCG companies like Dabur India, Emami. Marico, Tat Beverages etc. are known for their 
projects dedicated to women and children sanitation and empowerment (mortality, education, health, malnutrition, protection, equality, fair wages etc.). Despite all this, there is a little impact on their brand image and sales, due to ill fit CSR initiatives chosen by the firms.

Various initiatives by FMCG companies can be summarised as follows:

Nestle: Creating shared value (environmental protection \& community services). 'creating shared value' is a very different approach to CSR, because it is not focused on meeting a set of standard external criteria, or on philanthropy (by educating and imparting work skills to farmers, consuming lesser water and energy and producing fewer green hose gases, providing high quality products with good services, adopting best business practises etc).

Coca Cola: Environment protection, food safety \& quality, reduced carbon footprints, rain water harvesting, reduced water wastages, etc).

ITC: Focuses on Triple Bottom Line contributing to the growth of economy, environment and social development, raising agricultural productivity, education, social \& environmental initiatives, managing water soil level and forest resources, echoupal etc.

Britannia Industries Ltd: Corporate Citizenship, social development, improving quality of work life of its people, health and family welfare programs, clean drinking water, free education to poor etc.

Let us now have a look at the CSR report card of the top Indian corporates (India's top companies are ranked 1-100 based on Net Sales for the Financial Year 2012) as per the same survey.

Table 1

\begin{tabular}{|c|c|c|c|c|c|}
\hline $\begin{array}{l}\text { SR } \\
\text { NO. }\end{array}$ & COMPANY & REVENUE & AVG PAT & ACTUAL SPEND & $\begin{array}{l}2 \% \text { OF } \\
\text { PAT }\end{array}$ \\
\hline 1 & $\begin{array}{l}\text { INDIAN OIL } \\
\text { CORPORATION }\end{array}$ & 442,459 & 7,783 & 83 & 156 \\
\hline 2 & RELIANCE INDUSTRIES & 368,571 & 21,138 & 288 & 423 \\
\hline 3 & $\begin{array}{l}\text { BHARAT PETROLEUM } \\
\text { CORPORATION }\end{array}$ & 223,315 & 1,438 & 8 & 29 \\
\hline 4 & $\begin{array}{l}\text { HINDUSTAN PETRO- } \\
\text { LEUM CORPORATION }\end{array}$ & $195,89 \mid$ & 1,118 & 27 & 22 \\
\hline 5 & TATA MOTORS & 170,678 & 8,437 & 15 & 169 \\
\hline 6 & $\begin{array}{l}\text { OIL \& NATURAL GAS } \\
\text { CORPORATION }\end{array}$ & $|5|, 12 \mid$ & 23,660 & I2I & 473 \\
\hline 7 & STATE BANK OF INDIA & 147,197 & 13,056 & 71 & 261 \\
\hline 8 & TATA STEEL & 135,976 & 3,895 & 146 & 78 \\
\hline 9 & PNB GILTS & 104,628 & 29 & NA & I \\
\hline
\end{tabular}




\begin{tabular}{|c|c|c|c|c|c|}
\hline 10 & HINDALCO INDUSTRIES & 82,549 & 3,597 & 28 & 72 \\
\hline 11 & COAL INDIA & 78,410 & II,759 & 119 & 235 \\
\hline 12 & BHARTI AIRTEL & 71,506 & $6,5 \|$ & 33 & 130 \\
\hline 13 & MMTC & 67,023 & 129 & 3 & 3 \\
\hline 14 & NTPC & 66,366 & 9,334 & 49 & 187 \\
\hline 15 & LARSEN \& TOUBRO & 64,960 & 4,818 & 70 & 96 \\
\hline 16 & ESSAR OIL & 63,428 & -201 & NA & N/A \\
\hline 17 & MAHINDRA \& MAHINDRA & 63,030 & 2,948 & 22 & 59 \\
\hline 18 & $\begin{array}{l}\text { MANGALORE REFINERY } \\
\text { \& PETROCHEMICALS }\end{array}$ & 57,214 & I,066 & NA & 21 \\
\hline 19 & $\begin{array}{l}\text { TATA CONSULTANCY } \\
\text { SERVICES }\end{array}$ & 48,894 & 8,935 & 51 & 179 \\
\hline 20 & $\begin{array}{l}\text { BHARAT HEAVY } \\
\text { ELECTRICALS }\end{array}$ & 50,654 & 5,823 & 37 & 116 \\
\hline 21 & $\begin{array}{l}\text { STEEL AUTHORITY } \\
\text { OF INDIA }\end{array}$ & 51,428 & 5,153 & 61 & 103 \\
\hline 22 & GAIL (INDIA) & 44,861 & 3,891 & 54 & 78 \\
\hline 23 & $\begin{array}{l}\text { STERLITE INDUSTRIES } \\
\text { (INDIA) }\end{array}$ & 43,116 & 6,831 & 7 & 137 \\
\hline 24 & $\begin{array}{l}\text { CHENNAI PETROLEUM } \\
\text { CORPORATION }\end{array}$ & 45,397 & 392 & 3 & 8 \\
\hline 25 & ADANI ENTERPRISES & 39,416 & 1,940 & 14 & 39 \\
\hline 26 & ICICI BANK & 37,995 & 6,366 & 24 & 127 \\
\hline 27 & $\begin{array}{l}\text { PUNJAB NATIONAL } \\
\text { BANK }\end{array}$ & 37,447 & 4,460 & NA & 89 \\
\hline 28 & WIPRO & 37,308 & 5,152 & NA & 103 \\
\hline 29 & MARUTI SUZUKI INDIA & 40,050 & 2,162 & 12 & 43 \\
\hline 30 & JSW STEEL & 36,964 & I,569 & 32 & 31 \\
\hline 31 & INFOSYS & 33,734 & 7,128 & 26 & 143 \\
\hline 32 & $\begin{array}{l}\text { STATE TRADING } \\
\text { CORPORATION OF INDIA }\end{array}$ & 30,905 & 60 & NA & 1 \\
\hline 33 & CANARA BANK & 30,816 & 3,313 & NA & 66 \\
\hline 34 & BANK OF BARODA & 30,488 & 4,262 & NA & 85 \\
\hline 35 & $\begin{array}{l}\text { RUCHI SOYA } \\
\text { INDUSTRIES }\end{array}$ & 30,332 & 167 & 0 & 3 \\
\hline
\end{tabular}

source: http://forbesindia.com/article/real-issue/csr-report-card-where-companies-stand/34893/1 
According to the CSR India Index 2012, the top 10 private sector companies put together made a total of INR 734 billion in profit-after-tax for the financial year 2011-12 and CSR spend was only INR 6.9 billion instead of INR 14.67 billion (less than half of what is mandated in the company law i.e. $2 \%$ of net-profit).

\section{LITERATURE REVIEW}

Business philanthropy in India has developed in four phases. During the early years of industrialization (1850-1914), CSR in India was predominantly related to business philanthropy, as rich business families set up trusts and institutions such as schools, colleges, and hospitals. Gandhi, Nehru, Friedman, and Freeman respectively were champions of these four models. In the ethical model the focus is on "voluntary commitment by companies to public welfare", in the Statist model, "state ownership and legal requirements determine corporate responsibilities", in the liberal model "corporate responsibilities are limited to private owners", and in the stakeholder model "companies respond to the needs of stakeholders - customers, employees, communities, etc." (Kumar et al., 2001, p. 2). By the late 1980s, CSR had attracted worldwide attention and several scholars had determined that socially responsible companies enjoy a number of benefits. These include profitability factors, such as achieving a competitive advantage (Smith 1994; Porter and Kramer 2002); generating a positive corporate image (Smith and Stodghill 1994); attracting and retaining the best employees (Turban and Greening 1997); and enhancing customers' loyalty by increasing their general estimation of the company (Brown and Dacin 1997). Since the liberalization of the Indian economy in 1991, western-style ethical stances are being promoted hence even though the ethical, statist, and stakeholder models may be "idealized", the liberal (Friedman) model may be more influential in India, according to some authors (Balasubramanian et al., 2005).

The practice of CSR has been dominated by developments in Western developed countries, such as the United States of America (USA) and the United Kingdom (UK) (Chambers et al. 2003) and it is unclear whether it translates easily into developing and non-Western countries. There exist gaps between developed and developing countries when CSR is implemented (Chambers et al. 2003; Matten and Moon 2004; Chapple and Moon 2005; Visser 2007). Writers such as Edmondson and Carroll (1999), Burton et al. (2000) and Khan (2005), have suggested that different cultural models and traditional customs may mean that a great deal of what is currently understood about CSR may not be applicable in developing countries such as India or Sri Lanka.

For this reason, the theory and practice of CSR in developing countries such as needs to be discussed and debated at length and there is a need to examine whether prevailing Western notions of CSR can be implemented in developing countries (Jamali 2007), and whether CSR has positive business benefits (Dutta and Durgamohan 2008). Although various stakeholders have pushed companies to implement CSR in developing countries, it seems many firms do not have sufficient knowledge to actualize it (Fernando 2007). Moreover, there are no accepted rules in developing countries to enforce stakeholder demands (Chambers et al. 2003; Blowfield 2004; Chapple and Moon 2005; Thorpe and Prakash-Mani 2006; Visser 2008). Others suggest that manager's lack of understanding about the benefits of CSR inhibits its implementation (Fernando 2007; Agarwal 2008).

There has been a significant increase in interest in CSR in recent years. One study found that more than $80 \%$ of the Fortune 500 companies address CSR issues (Bhattacharya and Sen, 2004). According to Assocham Eco Pulse (2010-11), the maximum CSR initiatives have been undertaken by almost 52 companies in FMCG and consumer durable contributing a share of 13.11 per cent. Despite all this the FMCG sector has yet not focused too much into the social responsibility domain. 
Table 2: Dimensions of Corporate Social responsibility

\begin{tabular}{|c|c|c|c|}
\hline S. No & $\begin{array}{l}\text { Period of } \\
\text { Study }\end{array}$ & Focus Area & $\begin{array}{l}\text { Summary of } \\
\text { Dimensions }\end{array}$ \\
\hline 1 & \multirow{5}{*}{1950 's-1960's } & $\begin{array}{l}\text { Religious \& Humane } \\
\text { philosophies }\end{array}$ & \multirow{5}{*}{ Philanthropy } \\
\hline 2 & & Community development & \\
\hline 3 & & Unregulated philanthropy & \\
\hline 4 & & Poverty alleviation & \\
\hline 5 & & Obligation to the society & \\
\hline 6 & \multirow{7}{*}{1970 's-1980's } & Extension of CSR commitments & \multirow{7}{*}{ Regulated CSR } \\
\hline 7 & & $\begin{array}{l}\text { CSR as symbol of Corporate } \\
\text { citizenship }\end{array}$ & \\
\hline 8 & & $\begin{array}{l}\text { Stakeholder relationship } \\
\text { management } \\
\text { Corporate reputation }\end{array}$ & \\
\hline 10 & & Socio-economic priorities & \\
\hline 11 & & Bridging govemance gap & \\
\hline 12 & & Stakeholders rights & \\
\hline 13 & & Legal \& Ethical responsibilities & \\
\hline 14 & \multirow{5}{*}{$\begin{array}{l}1990^{\prime} \mathrm{s}-21^{\text {st }} \\
\text { century }\end{array}$} & Competitive strategy & \multirow{5}{*}{$\begin{array}{c}\text { Instrumental/Strategic } \\
\text { CSR }\end{array}$} \\
\hline 15 & & Environmental protection & \\
\hline 16 & & Sustainability & \\
\hline 17 & & $\begin{array}{l}\text { Intemationalization of CSR } \\
\text { standards }\end{array}$ & \\
\hline 18 & & Transparency \& accountability & \\
\hline
\end{tabular}

Source: Adapted from M Šontaitè-Petkevičienè, 2015

\section{CSR and Customer Orientation in the 21st century}

The following statement of Horrigan (2007) best portrays the status of CSR at the end of 21st century's first decade: Both the developed and developing worlds are rapidly reaching the point where they must decide if today's global CSR movement is a passing social fad, a threat to economically efficient corporate capitalism, an intrinsic element of corporate responsibility, or even a key to humanity's long-term survival. CSR literacy is quickly becoming a primary imperative for a variety of actors in a multiplicity of roles across governmental, business, and community sectors nationally and internationally.

Despite that our research target one specific stakeholder category (the customers) any CSR activity that increases some aspect of customer satisfaction also positively affect employees (and their families), the local community, and the society at large. Researches have confirmed the impact of the corporates' CSR activities on the consumer's attitude, behaviour and hence the purchase decisions. 


\section{CSR Trends in India}

FY 2015-16 witnessed a 28 percent growth in CSR spending in comparison to FY 2014-2015. Prime Minister's Relief Fund saw an increase of 418 percent from Rs 1.68 billion in 2014-15 to Rs 7.01 billion in 2015-16 The CSR spend of listed companies in India reached Rs 83.45 billion.

\section{Research Objective}

To study the Customer behaviour and Corporate Responsibility Activities for Indian Consumers (Carroll's Pyramid). For Testing the above objective the following Hypothesis were made.

\section{Hypothesis}

H01: There is no significant difference between customer behavior and economic Corporate Responsibility Activities for Indian Consumers.

HA1: There is significant difference between customer behavior and economic Corporate Responsibility Activities for Indian Consumers.

H02: There is no significant difference between customer behavior and legal Corporate Responsibility Activities for Indian Consumers.

HA2: There is significant difference between customer behavior and legal Corporate Responsibility Activities for Indian Consumers.

H03: There is no significant difference between customer behavior and ethical Corporate Responsibility Activities for Indian Consumers.

HA3: There is significant difference between customer behavior and ethical Corporate Responsibility Activities for Indian Consumers.

H04: There is no significant difference between customer behavior and philanthropic Corporate Responsibility Activities for Indian Consumers.

HA4: There is significant difference between customer behavior and philanthropic Corporate Responsibility Activities for Indian Consumers.

\section{Research Methodology}

The study design is exploratory and descriptive in nature and is based on a field survey of FMCG consumers.

\section{Data Collection Method}

Both primary and secondary data sources have been used to collect data \& answer research questions. Primary data mainly is obtained through the administering of questionnaires while secondary sources like past studies and archives were accessed from various databases.

\section{Selection of Sample}

The data was collected in the financial year 2015 2016. 800 questionnaires were distributed in the entire survey spread over 11 months from May 2015 - March 2016, out of which in all 564 were returned representing a response rate of $70.5 \%$. Some questionnaires were incomplete and were not included in the final sample. The final sample consisted of 468 usable questionnaires.

\section{STATISTICAL TOOLS AND TESTS USED}

(a) Reliability Coefficient Cronbach's alpha

(b) KMO and Barrlett's Test

(c) Weighted mean

(d) Coefficient of Correlation

(e) Multiple Regression Analysis

(f) Beta Coefficient of Regression equations

(g) Factor Analysis

(h) Kruskal - Wallis test, Chi - Square test and Mann - Whitney U test, Wilcoxon - W and Z test for Hypothesis Testing. 


\section{ANALYSIS AND INTERPRETATION}

Table 3: Cronbach's a for dimensions

\begin{tabular}{|l|c|c|}
\hline Dimensions & Number of Items & Cronbach's alpha \\
\hline Consumer Behaviour & 2 & 0.734 \\
\hline $\begin{array}{l}\text { Economic Corporate } \\
\text { Responsibility }\end{array}$ & 4 & 0.781 \\
\hline $\begin{array}{l}\text { Legal Corporate } \\
\text { Responsibility }\end{array}$ & 4 & 0.881 \\
\hline $\begin{array}{l}\text { Ethical Corporate } \\
\text { Responsibility }\end{array}$ & 4 & 0.924 \\
\hline $\begin{array}{l}\text { Philanthropic Corporate } \\
\text { Responsibility }\end{array}$ & 4 & 0.886 \\
\hline Total & 40 & 0.852 \\
\hline
\end{tabular}

Table 4: Descriptive Statistics

\begin{tabular}{|l|l|l|c|}
\hline Dimension & Mean & $\begin{array}{l}\text { Standard } \\
\text { Deviation }\end{array}$ & Conclusion \\
\hline Consumer Behaviour (X1) & 3.672 & 0.731 & Agree \\
\hline $\begin{array}{l}\text { Economic Corporate } \\
\text { Responsibility (Y1) }\end{array}$ & 3.519 & 0.663 & Agree \\
\hline $\begin{array}{l}\text { Legal Corporate } \\
\text { Responsibility (Y2) }\end{array}$ & 4.142 & 0.728 & Agree \\
\hline $\begin{array}{l}\text { Ethical Corporate } \\
\text { Responsibility (Y3) }\end{array}$ & 3.776 & 0.621 & Agree \\
\hline $\begin{array}{l}\text { Philanthropic Corporate } \\
\text { Responsibility (Y4) }\end{array}$ & 3.551 & 0.624 & \\
\hline
\end{tabular}

Table 5: Relationship between Consumer Behaviour and Economic Corporate Responsibility Activities

\begin{tabular}{|l|l|l|c|c|l|}
\hline \multirow{2}{*}{ Model } & \multicolumn{2}{|l|}{ Unstandardized Coefficients } & $\begin{array}{l}\text { Standardized } \\
\text { Coefficients }\end{array}$ & \multirow{2}{*}{ Sig. } \\
\cline { 2 - 5 } & \multicolumn{2}{|c|}{ B } & $\begin{array}{l}\text { Std. } \\
\text { Error }\end{array}$ & $\mathbf{B}$ & \\
\hline $\begin{array}{l}\text { (Constant) } \\
\text { ECRA }\end{array}$ & 1.772 & 0.000 & 0.804 & 13.442 & $\mathbf{0 . 0 0 0}^{*}$ \\
\hline
\end{tabular}

Table 6: Relationship between Consumer Behaviour and Legal Corporate Responsibility Activities

\begin{tabular}{|l|c|l|c|c|l|}
\hline \multirow{2}{*}{ Model } & \multicolumn{2}{|c|}{$\begin{array}{c}\text { Unstandardized } \\
\text { Coefficients }\end{array}$} & $\begin{array}{l}\text { Standardized } \\
\text { Coefficients }\end{array}$ & \multirow{2}{*}{\begin{tabular}{l} 
Sig. \\
\cline { 2 - 5 }
\end{tabular}} & \multicolumn{2}{|c|}{ B } & $\begin{array}{l}\text { Std. } \\
\text { Error }\end{array}$ & $\mathbf{B}$ & & \\
\hline \begin{tabular}{l|l} 
(Constant) \\
LCRA
\end{tabular} & 1.252 & 0.007 & 0.638 & 11.217 & $\mathbf{0 . 0 0 0}^{*}$ \\
\hline
\end{tabular}


Table 7: Relationship between Consumer Behaviour and Ethical Corporate Responsibility Activities

\begin{tabular}{|l|c|l|c|c|l|}
\hline \multirow{2}{*}{ Model } & \multicolumn{2}{|c|}{$\begin{array}{c}\text { Unstandardized } \\
\text { Coefficients }\end{array}$} & $\begin{array}{l}\text { Standardized } \\
\text { Coefficients }\end{array}$ & \multirow{2}{*}{$\begin{array}{l}\text { Sig. } \\
\end{array}$} \\
\cline { 2 - 5 } & \multicolumn{2}{|c|}{ B } & $\begin{array}{l}\text { Std. } \\
\text { Error }\end{array}$ & $\mathbf{B}$ & \\
\hline $\begin{array}{l}\text { (Constant) } \\
\text { ETCRA }\end{array}$ & 1.249 & 0.4471 & 0.942 & 14.724 & $\mathbf{0 . 0 0 0}^{*}$ \\
\hline
\end{tabular}

Table 8: Relationship between Consumer Behaviour and Philanthropic Corporate Responsibility Activities

\begin{tabular}{|l|c|l|c|c|l|}
\hline \multirow{2}{*}{ Model } & \multicolumn{2}{|c|}{$\begin{array}{c}\text { Unstandardized } \\
\text { Coefficients }\end{array}$} & $\begin{array}{l}\text { Standardized } \\
\text { Coefficients }\end{array}$ & \multirow{2}{*}{$\begin{array}{l}\text { Sig. } \\
\end{array}$} \\
\cline { 2 - 5 } & \multicolumn{2}{|c|}{ B } & $\begin{array}{l}\text { Std. } \\
\text { Error }\end{array}$ & B & \\
\hline $\begin{array}{l}\text { (Constant) } \\
\text { PCRA }\end{array}$ & 1.417 & 0.1841 & 0.942 & 11.414 & $\mathbf{0 . 0 0 0}^{*}$ \\
\hline
\end{tabular}

1. The null hypothesis was rejected as the study proved that there is significant relationship between customer behavior and Economic Corporate Responsibility Activities for Indian Consumers.

2. Alternative Hypothesis was accepted and a significant relationship between customer behaviour and Legal Corporate Responsibility Activities for Indian Consumers was found.

3. Thus, null hypothesis was rejected and alternative hypothesis was accepted. So, there is significant relationship between customer behavior and Ethical Corporate Responsibility Activities for Indian Consumers.

4. The study found that there is a significant relationship between customer behavior and Philanthropic Corporate Responsibility Activities for Indian Consumers.

\section{CONCLUSION}

Customers are involved in rational purchase decisions, technology allows the common man to access information and interpret it wisely. Doing anything in the name of CSR is certainly not going to work for the organizations (Raheja Shivani, 2014). Corporates need to be carefully segmenting, targeting and positioning themselves in the CSR domain to project the right social image and needs to be selective while going for social initiatives. The CSR must be viewed from the eyes of the consumers. Self-satisfying/superlative moves enacted under the pretext of CSR initiatives may prove detrimental for the growth and the reputation for the company. There is a need to understand what is required and is important from customer's point of view. The initiatives well associated and valued by customers enhances the brand image of the organization in the eyes of its customers and increases manifold the loyalty of the customers towards the firm (Raheja Shivani, 2017). Also, socially motivated proactive moves need to be rightly supplemented by a cautious effort of marketing and communicating the same to its customers. However, the bottom line is that the CSR initiatives in India are now seriously taken by many companies. Especially for the FMCG companies, where the major challenge is reduction of packaging materials, these companies are doing work in the field of Environment, Health care, Education, Community welfare, Women's empowerment and Girl Child care. Leading FMCG companies fail to leverage their web sites in terms of educating the consumers about their CSR intent and activities. Another interesting study highlighted that 
the consumers expect firms to be involved in social initiatives and may reward them for their efforts through their positive purchase behaviour. Handpicked CSR projects will not just enhance the company's goodwill manifold but will certainly bring a positive shift in the sales and long term profitability/sustainability of the firm. The effect of CSR spending can be studied with other financial measures to judge its effect on overall profitability, share prices (Sapra Ritu, 2016) etc.

\section{REFERENCES}

1) Bhattacharya C. and Sen S. (2004) Doing Better at Doing Good: When, Why and How Consumers Respond to Corporate Social Initiatives California Management Review 47(1), 9-25.

2) Brown, Tom J. and Peter A. Dacin. 1997. "The Company and the Product: Corporate Associations and Consumer Product Responses." Journal of Marketing 61 (January): 68-85.

3) Burton B. and Goldsby M. (2009) Corporate Social Responsibility Orientation, Goals and Behaviour: A Study of Small Business Owners Business \& Society 48(1), 88-104.

4) Burton, BK, Farh, JL \& Hegarty, WH 2000, 'A cross-cultural comparison of corporate social responsibility orientation: Hong Kong vs. United States students', Teaching Business Ethics, vol. 4, no. 2, pp. 151-67.

5) Carroll A. (1998) The Four Faces of Corporate Citizenship Business \& Society Review 100(1), 17.

6) Carroll, A. B. (1979). A Three-Dimensional Model of Corporate Performance. Academy of Management Review, 4[4], p. 497-505.

7) Carroll, A. B. (1991). The Pyramid of Corporate Social Responsibility: Toward the Moral Management of Organizational Stakeholders. Business Horizons, 34, p. 39-48.

8) Carroll, A. B., \& Shabana, K. M. (2010). The Business Case for Corporate Social Responsibility: A Review of Concepts, Research and Practice. International Journal of Management Reviews, 12(1), 85-105.

9) Carroll, A.B. (1979). A three-dimensional conceptual model of corporate social performance. Academy of Management Review, 4, pp. 497-505.

10) Carroll, A.B. (1999). Corporate social responsibility: evolution of a definitional construct. Business and Society, 38, pp. 268-295.

11) Carroll, A.B. (2008). A history of corporate social responsibility: concepts and practices. In Crane, A., McWilliams, A., Matten, D., Moon, J. and Siegel, D. (eds), The Oxford Handbook of Corporate Social Responsibility. Oxford: Oxford University Press, pp. 19-46.

12) Chambers, E, Chapple, $W$, Moon, J \& Sullivan, $M$ 2003, 'CSR in Asia: A seven country study of CSR website reporting'.

13) Chapple, W., and Moon, J. 2005. 'Corporate Social Responsibility in Asia: A Seven-Country Study of CSR Web Site Reporting'. Business \& Society, 44(4): 415-41.

14) Du, Bhattacharya, C. B., \& Sen, S. (2010). Maximizing Business Returns to Corporate Social Responsibility (CSR): The Role of CSR Communication. International Journal of Management Reviews, 12(1), 8-19.

15) Dutta, K., \&Durgamohan, M. (2008). Corporate Social Strategy: Relevance and pertinence in the Indian context. Institute for international management and technology. http://www.iitk.ac.in/infocell/announce/conv ention/papers/Industrial $\% 20$ Economics $\% 20 \% 20$ E n v i r o n m e n t, \% 20 C S R - 08 Kirti\%20Dutta,\%20M\%20Durgamohan.pdf

16) Edmondson, V. C. \& Carroll, A. B. (1999). Giving Back: An Examination of the Philanthropic Motivations, Orientations and Activities of Large Black-Owned Businesses. Journal of Business Ethics, 19[2], p. 171-179.

17) Fernando, M. 2007. 'Corporate Social Responsibility in the Wake of the Asian Tsunami: A Comparative Case Study of Two Sri Lankan Companies'. European Management Journal, 25(1): 1-10.

18) Freeman E. and Reed D. (1983) Stockholders and Stakeholders: A New Perspective on Corporate Governance California Management Review 25(3), 88-106. 
19) Friedman, M. (1970). 'The social responsibility of business is to increase its profits. New York Times Magazine, September, 13.

20) Horrigan, B 2007, '21st century corporate social responsibility trends - An emerging comparative body of law and regulation on corporate responsibility, governance and sustainability, Macquarie Journal of Business Law, vol. 4, no. 1, pp. 85-122.

21) Khan, S 2005, 'Exploring the concept of sustainability in emerging markets: Evidences from the Indian pharmaceutical industry', URL: http://www. oikosstiftung. unisg. ch/academy2005/paper_khan. pdf>

22) Luo, X., \& Bhattacharya, C. B. (2009). The Debate over Doing Good: Corporate Social Performance, Strategic Marketing Levers, and FirmIdiosyncratic Risk. Journal of Marketing, 73, 198213.

23) M. E. Porter and M. R. Kramer, "The Competitive Advantage of Corporate Philanthropy," Harvard Business Review, Vol. 80, No. 9, 2002, pp. 56-69.

24) Matten, D \& Moon, J 2004, 'Corporate Social Responsibility Education in Europe', Journal of Business Ethics, vol. 54, no. 4, pp. 323-37.

25) Matten, D \& Moon. 2008, '" Implicit" and" explicit" CSR: a conceptual framework for a

comparative understanding of corporate social responsibility', The Academy of Management Review (AMR), vol. 33, no. 2, pp. 404-24.

26) Matten, D., \& Crane, A. 2005. Corporate citizenship: Toward an extended theoretical conceptualization. Academy of Management Review, 30: 166 -179.

27) Miglè Šontaitė-Petkevičienè. 2015. CSR Reasons, Practices and Impact to Corporate Reputation. Procedia - Social and Behavioral Sciences 213, 503508.

28) Moon, J. (2002), “Corporate social responsibility: an overview," in International Directory of Corporate Philanthropy, Europa, London: UK, pp. 385-408.

29) Moon, J. (2007), “The contribution of corporate social responsibility to sustainable development," Sustainable Development, vol. 15, no. 5, pp. 296-306.
30) Moon, S.-G., \& deLeon, P. (2007). Contexts and Corporate Voluntary Environmental Behaviors: Examining the EPA's Green Lights Voluntary Program. Organization Environment, 20(4), 480496.

31) Porter, M, E. \& Kramer, M, R 2002, 'The competitive advantage of corporate philanthropy', Harvard Business Review, vol. 80, no. 12, pp. 56-68.

32) Porter. (2008). Managerial applications of corporate social responsibility and systems thinking for achieving sustainability outcomes. Systems Research and Behavioral Science, 25(3), 397-411.

33) Raheja Shivani (2014). CSR: A Social Responsibility or a Social Show off (Sustainability Versus Sham)". Jigyasa 2014, Journal of Human Resource and Organizational Development, 33- 36.

34) Raheja Shivani (2017). A study on Consumer's Perception about Corporate Social Activities/Responsibilities with special reference to companies in FMCG sector of India. International Conference on Paradigm Shift in World Economies: Opportunities and Challenges, (IC- PSWEOC - 2017), ISBN: 978-163535-729-5, pg:68-80.

35) Raheja Shivani (2014). Customer perspective: A new way of doing CSR by FMCG companies to leverage Business, "Paradigm Shift in Contemporary Management" page no 11-19, by Pragati Publications, New Delhi, First Edition, 2014, ISBN 978-81-7307-145-4.

36) Raheja Shivani (2017). “CSR Activities and Responsibilities by FMCG Companies of India: A Customer Perspective", Effulgence, the Refereed Management Journal of RDIAS, GGSIPU, ISSN:0972-8058.

37) Raheja Shivani (2017). “Consumers perception about CSR Activities and Responsibilities of FMCG Companies in India", South Asian Journal of Socio- Political Studies, SAJOSPS, ISSN: 0972-4613.

38) Sapra Ritu et al. "CSR Spending and its Relationship with Share Prices (with Special Reference to Top Indian Auto Ancillary Companies in Light of Companies Act 2013)". 
pg: 28-36. Effulgence, Vol. 14, No.2, July December, 2016. ISSN: 0972-8058.

39) Sen, S., Bhattacharya, C. B., \& Korschun, D. (2006). The role of corporate social responsibility in strengthening multiple stakeholder relationships: A field experiment. Journal of the Academy of Marketing Science, 34(2), 158-159.

40) Smith J. (2003) The Shareholder Versus Stakeholder Debate Sloan Management Review 44(4) 85-91.

41) Smith, C 1994, 'The new corporate philanthropy', Harvard Business Review, vol. 72, no. 3, p. 105.

42) Smith, G \& Stodghill, R 1994, 'Are good causes good marketing?', Business Week, vol. 21, pp. 645.

43) Thorpe, J., \& Prakash-Mani, K. (2006). Developing Value. Greener Management International: The Journal of Corporate Environmental Strategy and Practice (GMI), 1732.

44) Turban, D. B., \& Greening, D. W. 1997. Corporate social performance and organizational attractiveness to prospective employees. Academy of Management Journal, 40: 658-72.

45) Visser, W. (2008)._Corporate Social Responsibility in Developing Countries' The Oxford Handbook of Corporate Social Responsibility. Oxford: Oxford University Press.

46) Visser, W. 2007b. 'Corporate social responsibility in developing countries', The Oxford Handbook of Corporate Social Responsibility (Oxford University Press, Oxford), pp. 473-9. 